\title{
Human Bone Marrow- and Adipose Tissue-derived Mesenchymal Stromal Cells are Immunosuppressive In vitro and in a Humanized Allograft Rejection Model
}

Marieke Roemeling-van Rhijn ${ }^{1 *}$, Meriem Khairoun ${ }^{2}$, Sander S Korevaar ${ }^{1}$, Ellen Lievers ${ }^{2}$, Danielle G Leuning², Jan NM IJzermans ${ }^{3}$, Michiel GH Betjes ${ }^{1}$, Cees van Kooten², Hans JW de Fijter ${ }^{2}$, Ton J Rabelink², Carla C Baan ${ }^{1}$, Willem Weimar', Helene Roelofs ${ }^{4}$, Martin J Hoogduijn ${ }^{1}$ and Marlies E Reinders ${ }^{2}$

${ }^{1}$ Internal Medicine, Erasmus MC, Rotterdam, The Netherlands

${ }^{2}$ Nephrology, Leiden University Medical Center, The Netherlands

${ }^{3}$ General Surgery, Erasmus MC, Rotterdam, The Netherlands

${ }^{4}$ Immunohematology and blood transfusion, Leiden University Medical Center, The Netherlands

\begin{abstract}
Background: Recent studies with bone marrow (BM)-derived Mesenchymal Stromal Cells (MSC) in transplant recipients demonstrate that treatment with MSC is safe and clinically feasible. While BM is currently the preferred source of MSC, adipose tissue is emerging as an alternative. To develop efficient therapies, there is a need for preclinical efficacy studies in transplantation. We used a unique humanized transplantation model to study the in vivo immunosuppressive effect of human BM-MSC and adipose tissue-derived MSC (ASC).

Methods: Gene expression of BM-MSC and ASC and their capacity to inhibit activated PBMC proliferation was evaluated. The in vivo immunosuppressive effect of BM-MSC and ASC was studied in a humanized mouse model. SCID mice were transplanted with human skin grafts and injected with human allogeneic PBMC with or without administration of BM-MSC or ASC. The effect of MSC on skin graft rejection was studied by immunohistochemistry and PCR.

Results: BM-MSC and ASC expressed TGF $\beta, C X C L-10$ and IDO. IDO expression and acitivity increased significantly in BM-MSC and ASC upon IFN-y stimulation. IFN-y stimulated BM-MSC and ASC inhibited the proliferation of activated PBMC in a significant and dose dependent manner. In our humanized mouse model, alloreactivity was marked by pronounced CD45+ T-cell infiltrates consisting of CD4+ and CD8+ T cells and increased IFN-y expression in the skin grafts which were all significantly inhibited by both BM-MSC and ASC.
\end{abstract}

Conclusion: BM-MSC and ASC are immunosuppressive in vitro and suppress alloreactivity in a preclinical humanized transplantation model.

Keywords: Adipose tissue; Allograft rejection; Bone marrow; Immunomodulation; Mesenchymal stromal cells

Abbreviations: ASC: Adipose Tissue Derived Mesenchymal Stromal Cells; BM: Bone Marrow; BM-MSC: Bone Marrow Derived Mesenchymal Stromal Cells; MSC: Mesenchymal Stromal Cells; PBMC: Peripheral Blood Mononuclear Cells

\section{Introduction}

In the last decades, the interest in Mesenchymal Stromal Cells (MSC) as a cell therapeutic agent has grown substantially [1-5]. These fibroblast-like, plastic adherent cells have multipotent differentiation capacity and while they were originally isolated from bone marrow $(\mathrm{BM})$, they can be isolated from virtually all tissues, including adipose tissue [6-10]. In absence of a specific marker, MSC are commonly defined by a panel of cell surface markers; including CD73, CD90, CD105 and CD166; and their multilineage differentiation capacity [11].

MSC are immunosuppressive cells as indicated by their capacity to inhibit activated $\mathrm{T}$ cell proliferation in vitro $[12,13]$. This immunosuppressive potential is enhanced under inflammatory conditions in which IFN $\gamma$ plays an important role $[14,15]$. In animal studies, the potential of MSC has been confirmed in multiple disease models for conditions including Graft versus Host Disease (GvHD) $[16,17]$; ischemia-reperfusion-induced renal injury $[18,19]$; and liver failure $[20,21]$. Subsequently, several clinical studies have been conducted evaluating MSC therapy in amongst others GvHD [22]; end stage liver disease [23] and Crohn's disease [24].
In the field of transplantation, MSC are of great interest due to their potential to inhibit the alloimmune response as well as to contribute to tissue repair. Animal transplant studies showed that MSC are capable to inhibit acute rejection and or to prolong allograft survival [25-28]. As a result, MSC have been applied in kidney transplant recipients [2931] and a study with MSC in liver transplantation has been initiated [32]. Recent studies, including ours, showed the safety and feasibility of autologous MSC treatment in kidney transplant recipients when using BM-MSC in renal transplant recipients with subclinical rejection or as induction therapy [29-31,33]. While these studies are indicative of an immunomodulatory effect of MSC in human, efficacy of MSC therapy in clinical transplantation remains to be determined.

*Corresponding author: Marieke Roemeling-van Rhijn, Erasmus University Medical Center, Transplant Laboratory Internal Medicine Room No: 319, P.O. box 20403000 CA Rotterdam, The Netherlands, Tel: +31(0)10-7035421; Fax: +31(0)10-7044718; E-mail: mariekevan.rhijn@gmail.com

Received November 06, 2013; Accepted November 22, 2013; Published November 25, 2013

Citation: Roemeling-van Rhijn, Khairoun M, Korevaar SS, Lievers E, Leuning DG, et al. (2013) Human Bone Marrow- and Adipose Tissue-derived Mesenchymal Stromal Cells are Immunosuppressive In vitro and in a Humanized Allograft Rejection Model. J Stem Cell Res Ther S6: 001. doi:10.4172/2157-7633.S6-001

Copyright: (c) 2013 Roemeling-van Rhijn, et al. This is an open-access article distributed under the terms of the Creative Commons Attribution License, which permits unrestricted use, distribution, and reproduction in any medium, provided the original author and source are credited. 
Citation: Roemeling-van Rhijn, Khairoun M, Korevaar SS, Lievers E, Leuning DG, et al. (2013) Human Bone Marrow- and Adipose Tissue-derived Mesenchymal Stromal Cells are Immunosuppressive In vitro and in a Humanized Allograft Rejection Model. J Stem Cell Res Ther S6: 001. doi:10.4172/2157-7633.S6-001

Page 2 of 8

Currently, BM is the most commonly used source of MSC. However, BM aspiration is an invasive procedure accompanied with donor morbidity. In contrast, adipose tissue can be obtained in a minimal invasive way via lipectomy or liposuction and is therefore emerging as an alternative [34]. Bone marrow has a lower yield of MSC compared to adipose tissue, and adipose tissue derived MSC (ASC) have a higher proliferation capacity than bone marrow derived MSC (BM-MSC) [35-37]. Considering their basic features, BM-MSC and ASC show many resemblances. Both BM-MSC and ASC express the classical MSC markers CD73, CD90, CD105 and CD166 [36,37] although some differences in immunophenotype between BM-MSC and ASC have been reported [34,38,39]. BM-MSC and ASC both display the spindle shape MSC morphology and they are both capable of multilineage differentiation. Immunosuppressive capacities in vitro have been acknowledged for BM-MSC [12,40,41] and ASC [6,42-44]. In animals transplant models, both BM-MSC $[12,25-27,45,46]$ and ASC [28] have shown to be beneficial in inhibiting acute rejection and or increasing allograft survival. The efficacy of BM-MSC and ASC in humanized transplant models has however never been investigated. In the present study we focus on the immunomodulatory effects of BM-MSC and ASC in vitro and in a humanized skin allograft rejection model.

\section{Materials and Methods}

\section{Bone marrow and adipose tissue donors}

MSC were isolated from either BM or adipose tissue from healthy controls. BM was obtained from 5 hematopoietic stem cell donors after written informed consent as approved by the Medical Ethical Committee of Leiden University Medical Centre as described before [47]. Adipose tissue was obtained from 9 live kidney donors after written informed consent as approved by the Medical Ethical Committee of the Erasmus MC (protocol no. MEC-2006-190).

\section{BM-MSC isolation and culture}

$\mathrm{BM}$ was aspirated under general anesthesia. The mononucleated cell (MNC) fraction was isolated by Ficoll density gradient separation and plated in tissue culture flasks at a density of $160 \times 10^{3} \mathrm{MNC} / \mathrm{cm}^{2}$ in low-glucose Dulbecco's modified Eagle medium DMEM (Invitrogen, Paisley, UK) supplemented with penicillin/streptomycin (Lonza, Verviers, Belgium) and 10\% fetal calf serum (FCS, Thermo Scientific HyClone)). The cultures were maintained at $37^{\circ} \mathrm{C}, 5 \% \mathrm{CO}_{2}$. The medium was refreshed twice a week. When the MSC cultures became confluent, cells were collected using trypsin (Lonza) and re-plated at a density of $4 \times 10^{3}$ cells $/ \mathrm{cm}^{2}$ or frozen until further usage.

\section{ASC isolation and culture}

Abdominal subcutaneous adipose tissue was surgically removed under general anaesthesia during donor nephrectomy. Adipose tissue was mechanically disrupted and enzymatically digested with sterile $0.5 \mathrm{mg} / \mathrm{ml}$ collagenase type IV (Sigma-Aldrich, St Louis, MO) in RPMI-1640 p gluta MAX (Invitrogen) and $\mathrm{p} / \mathrm{s}$ for $30 \mathrm{~min}$ at $37.1^{\circ} \mathrm{C}$. Cell pellets were resuspended in MSC culture medium, consisting of MEM- $\alpha$ (Sigma-Aldrich(St. Louis, MO, USA) with $1 \% \mathrm{p} / \mathrm{s}$ and $15 \%$ fetal bovine serum (BioWhittaker, Verviers, Belgium), transferred to a $175-\mathrm{cm}^{2}$ culture flask (Greiner Bio-one, Essen, Germany) and kept at $37^{\circ} \mathrm{C}$ and $5 \% \mathrm{CO}_{2}$. Medium was refreshed twice a week. When ASC cultures became $90 \%$ confluent, cells were detached using $0.05 \%$ trypsin-EDTA and frozen until further usage.

For experiments, only passage 1-5 BM-MSC and ASC were used.
Prior to usage for experiments BM-MSC and ASC were cultured in parallel under the same culture conditions.

\section{Isolation of peripheral blood mononuclear cells (PBMCs)}

PBMCs were collected from buffy coats of healthy blood bank donors (different than the MSC donors). PBMCs were isolated by density gradient centrifugation using Ficoll Isopaque (Pharmacia Amersham, Uppsala, Sweden) and used directly or frozen at $-135^{\circ} \mathrm{C}$ until use.

\section{Real-time RT-PCR}

For evaluation of mRNA gene-expression by BM-MSC and ASC, 100,000 MSC were seeded per well in a 6 well plate in either normal MSC culture medium or MSC culture medium supplemented with 100 $\mathrm{ng} / \mathrm{ml}$ IFN $\gamma$. After 24 hours, MSC cell pellets were harvested.

RNA was isolated and cDNA synthesized as described previously [48]. Quantitative expression was determined by real-time RT-PCR using universal PCR mix (Invitrogen) and Assays- on-demand for IDO (Hs00158627.m1), TGF- $\beta$ (Hs00171257.m1) and CXCL-10 (Hs 00171042.m1) on a StepOnePlus real time PCR system (Applied Biosystems). Gene-expression was depicted as ratio with GAPDH.

\section{IDO activity measurements}

BM-MSC and ASC were cultured in standard MSC culture medium or culture medium supplemented with $100 \mathrm{ng} / \mathrm{ml}$ IFN $\gamma$. After 1 week, medium was removed and BM-MSC and ASC were washed twice with $1 \times$ PBS. Next, BM-MSC and ASC were cultured for 24 hours in serum free MEM- $\alpha(+1 \% \mathrm{p} / \mathrm{s})$ before medium was harvested. The tryptophan metabolic activity of IDO was determined by measurement of L-kynurenine in the conditioned medium of four unstimulated and four stimulated BM-MSC and ASC cultures. 30\% trichloroacetic acid was added to the samples at a 1:3 ratio and after $30 \mathrm{~min}$ incubation at $50^{\circ} \mathrm{C}$ the samples were centrifuged at 12,000 $\mathrm{rpm}$ for $5 \mathrm{~min}$. Supernatants were then diluted 1:1 in Ehrlich reagent (200 mg 4-dimethylaminobenzaldehyde (Sigma, St. Louis, MO, USA) in $10 \mathrm{ml}$ of glacial acetic acid) in duplicate in a 96-wells flat bottom plate and absorbance was determined at $490 \mathrm{~nm}$ using a multilabel plate reader (VersaMaxTM, Molecular Devices, Sunnyvale, CA, USA). L-kynurenine (Sigma, St. Louis, MO, USA) diluted in unconditioned medium was used as standard.

\section{Anti-CD3/CD28 lymphocyte stimulation assay}

MSC were seeded in round bottom 96-wells plates in MEMa with $10 \%$ heat inactivated human serum at $0.125 \times 10^{4} ; 0.25 \times 10^{4} ; 0.5 \times$ $10^{4} ; 1 \times 10^{4}$ or $2 \times 10^{4}$ cells per well. PBMCs were stimulated with antihuman-CD3 $\left(0.5 \mathrm{ug} / 5 \times 10^{5}\right.$ cells $)$, anti-human-CD28 $\left(0.5 \mathrm{ug} / 5 \times 10^{5}\right.$ cells), and goat-anti-mouse antibody $\left(0.5 \mathrm{ug} / 5 \times 10^{5}\right.$ cells $)$ for crosslinking (all BD Pharmingen).

PBMCs were added to the round-bottom 96-well plates at $5 \times$ $10^{4}$ cells per well. Proliferation was measured by incorporation of ${ }^{3} \mathrm{H}$-thymidine $(0.5 \mu \mathrm{Ci})$ during $8 \mathrm{~h}$ using a beta-plate reader $(\mathrm{LKB})$ on day 3. All experiments were performed in triplicate and medians were used for further analysis.

\section{Humanized SCID mouse allograft model}

Animals: CB-17 SCID/mice were obtained from Charles River Laboratories (Wilmington, Massachusetts, USA) and were used at age 8-10 weeks. The Animal Care and Use Committee of the Leiden University Medical Center approved all experiments. Animals were 
Citation: Roemeling-van Rhijn, Khairoun M, Korevaar SS, Lievers E, Leuning DG, et al. (2013) Human Bone Marrow- and Adipose Tissue-derived Mesenchymal Stromal Cells are Immunosuppressive In vitro and in a Humanized Allograft Rejection Model. J Stem Cell Res Ther S6: 001. doi:10.4172/2157-7633.S6-001

Page 3 of 8

housed under specific pathogen free conditions in individually ventilated cages and allowed free access to food and water throughout the experiments.

Humanized SCID model: The humanized skin allograft model was approved by local medical ethical committee and local animal ethical committee. The study is based on the model described by Moulton et al. with slight adaptations [49]. In summary, human abdominal skin was obtained from healthy individuals who underwent elective plastic surgery procedures. Eight-mm punch biopsies were harvested and kept in culture medium and transplanted onto the back of CB-17 SCID mice within 12 hours. The mouse skin was shaved and skin grafts were fixed with a transparent adhesive film (Smith and Nephew, Hoofddorp, Netherlands) and allowed to heal for 4-6 weeks. For humanization, third party peripheral blood mononuclear cells (PBMCs) were isolated from fresh buffy coats, obtained from healthy controls, as described before.

All animals received $100 \mu \mathrm{l}$ of anti-asialo GM1 by intraperitoneal injection to deplete host NK cells at day-1 (Wako Chemicals USA, Richmond, VA, USA). At day 0, 24 hours after administration of antiasialo, $3 \times 10^{8}$ PBMCs were transferred by intraperitoneal injection.
MSC were cultured for 1 week in the presence of $100 \mathrm{ng} / \mathrm{ml} \mathrm{IFN} \gamma$ (PeproTech EC Ltd, London, UK) before injection into SCID mice.

BM-MSC $\left(0.5 \times 10^{6}\right.$ per infusion, $\mathrm{n}=8$ mice $)$ or ASC $\left(0.5 \times 10^{6}\right.$ per infusion, $\mathrm{n}=7$ mice) were injected under the skin graft at day 0 and 4. Control mice $(n=9)$ received $100 \mu$ l saline at the same time points. Animals were sacrificed at day 14 days and skin grafts were harvested. The humanized SCID model is depicted in Supplementary Digital Content (SDC), Figure 1.

Immunohistochemistry: Immunohistochemical staining was performed as described previously [50]. Skin sections $(4 \mu \mathrm{m})$ of snapfrozen skins grafts were air dried and acetone fixed. Slides were incubated overnight with mouse monoclonal IgG against human leukocytes (CD45; BD Pharminghen, Breda Netherlands) or cytotoxic T-lymphocytes (CD8; Millipore, Amsterdam Netherlands) and rabbit polyclonal antiCD3 (NeoMarkers, Fremont, California, USA). Antibody binding was detected with horseradish peroxidase (HRP)-labeled goat anti-mouse IgG and goat anti-rabbit IgG (both DAKO, Glostrum, Germany). After washing, sections were incubated with tyramide-fluorescein itransplantationhiocyanate in tyramide buffer (NENTM Life Science Products, Boston, MA, USA), washed and incubated with HRP-labeled

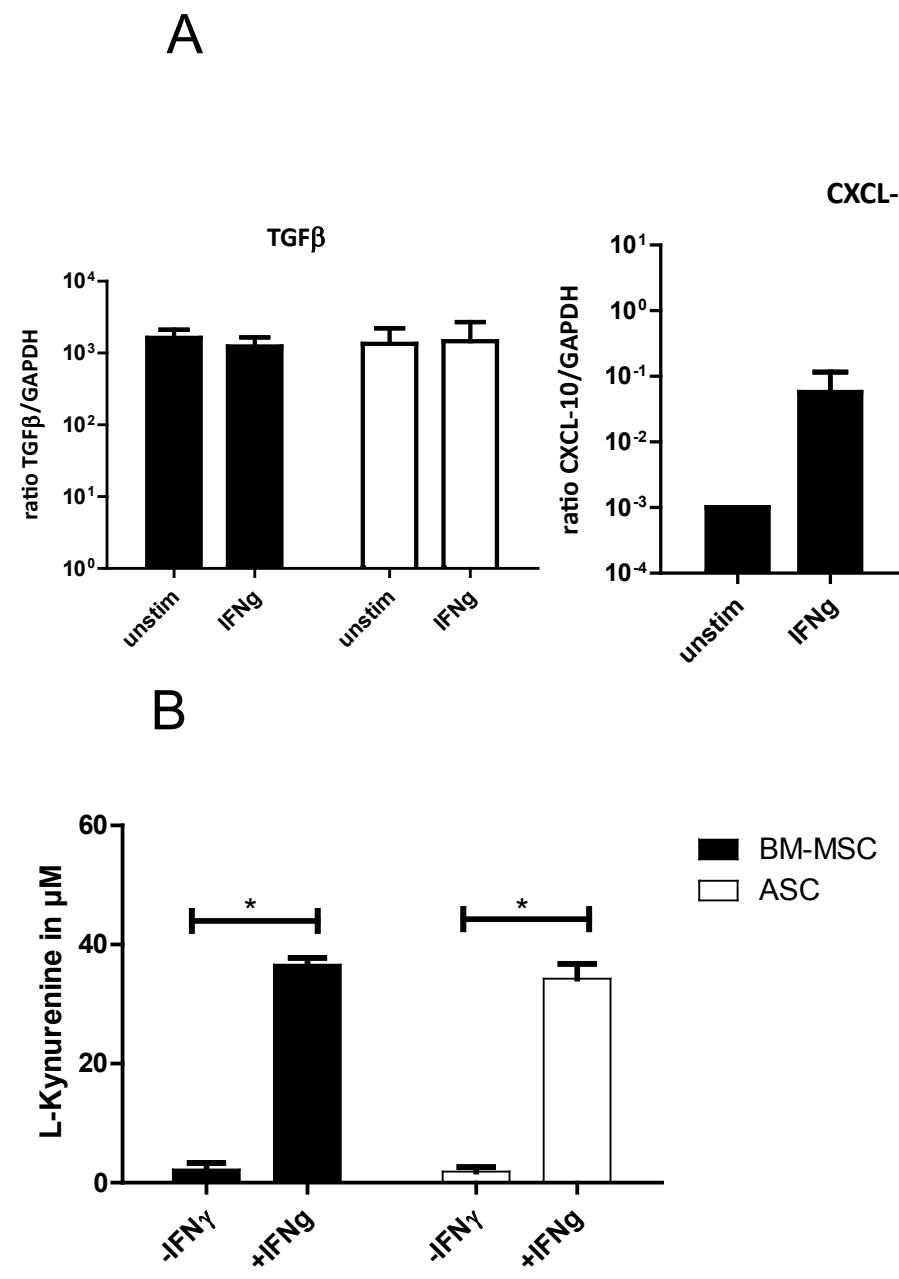

Figure 1: (A) mRNA gene expression of immunomodulatory genes of BM-MSC and ASC with or without IFNy stimulation, $n=5$ for BM-MSC and $n=5$ for ASC. Ratio gene/GAPDH $\times 1000$ is shown. Means (SD) are depicted, "represents $P<0.05$. (B) Effect of IFNy stimulation on IDO activity in BM-MSC and ASC determined by measurement of L-kynurenine in medium conditioned with unstimulated or IFNy stimulated BM-MSC and ASC, $n=4$ for BM-MSC and $n=4$ for $A S C$, means (SD) are depicted, "represents $\mathrm{P}<0.05$. 
Citation: Roemeling-van Rhijn, Khairoun M, Korevaar SS, Lievers E, Leuning DG, et al. (2013) Human Bone Marrow- and Adipose Tissue-derived Mesenchymal Stromal Cells are Immunosuppressive In vitro and in a Humanized Allograft Rejection Model. J Stem Cell Res Ther S6: 001. doi:10.4172/2157-7633.S6-001

Page 4 of 8

rabbit anti-fluorescein itransplantationhiocyanate (DAKO, Glostrum, Germany) and developed with 3,3'-Diaminobenzidine (DAB) (Sigma, St Louis, MO, USA). Sections were counterstained with haematoxylin (Merck, Darmstadt, Germany) and mounted with imsol (Klinipath, Duiven, the Netherlands). Quantification of immunohistochemistry was performed in a blinded manner by assessing 10 consecutive high power fields (magnification, $\times 200$ ) on each section. Using Image $J$ software, the percentage positive area in each image was determined.

Real-time RT-PCR: RNA was isolated from explanted skingrafts using TRIzol Reagent (Life technologies) and RNeasy minikit (Qiagen, Venlo, The Netherlands) according to manufacturer's recommendations. Quantitative expression was determined by realtime RT-PCR as described above using Assays- on-demand for IFN $\gamma$ (Hs 00174086.m1), TNF- $\alpha$ (Hs99999043.m1), IL1- $\beta$ (Hs00174097.m1), IL-6 (Hs 00174131.m1) and GAPDH (Hs 99999905.m1) (all Applied Biosystems, Foster City, CA). Gene-expression was depicted as ratio with GAPDH.

\section{Statistical analyses}

Mann Whitney statistical test was used to test for statistical significance, $p$ value $<0.05$ was considered statistical significant.

\section{Results}

\section{Bone marrow and adipose tissue donors}

Study tissues were collected from healthy BM donors $(n=5$, mean age 15 years, range 7-31 years) and healthy adipose tissue donors ( $n=5$, mean age 54 years, range 32-67 years). The expanded MSC from healthy BM and adipose tissue donors all expressed the common MSC markers CD73, CD90, CD105 and CD166 (data not shown).

\section{BM-MSC and ASC express immunomodulatory genes}

Both BM-MSC and ASC expressed TGF- $\beta$, CXCL-10, and IDO mRNA (Figure 1A). Since MSC are activated under inflammatory conditions, we investigated the effect of the pro-inflammatory cytokine IFN $\gamma$ on BM-MSC and ASC gene expression. Expression of TGF $\beta$ and CXCL-10 mRNA was not affected by 1 week of IFN $\gamma$ stimulation. However, IDO mRNA expression was increased both in BM-MSC and ASC after IFN $\gamma$ stimulation.

\section{IDO activity increases after IFN $\gamma$ stimulation in BM-MSC} and ASC

To evaluate whether increased IDO mRNA expression was translated in enhanced IDO activity upon IFN $\gamma$ stimulation of BMMSC and ASC, we studied the concentrations of L-kynurenine in BM-MSC and ASC conditioned medium. In medium conditioned with IFN $\gamma$ stimulated BM-MSC and ASC, levels of L-kynurenine were significantly higher compared to medium conditioned with unstimulated BM-MSC and ASC (Figure 1B). As L-kynurine is the breakdown product of tryptophan, this indicates an increase of the tryptophan depleting activity of IDO in BM-MSC and ASC after IFN $\gamma$ stimulation, which is suggestive for immunosuppressive activity of BM-MSC and ASC.

\section{BM-MSC and ASC have immunosuppressive properties in vitro}

We then compared the immunosuppressive capacity of IFN $\gamma$ stimulated BM-MSC and ASC. The canacity of these stimulated MSC to inhibit the proliferation of $\alpha \mathrm{CD} 3 \alpha \mathrm{CD} 28$ activated PBMCs was evaluated. Both IFN $\gamma$ stimulated BM-MSC and ASC were capable of significant and dose dependent inhibition of $\alpha \mathrm{CD} 3 a \mathrm{CD} 28$ activated PBMC proliferation. The BM-MSC group showed significant inhibition until a MSC: PBMC ratio of 1:10, ASC until a MSC: PBMC ratio of 1:20. No significant difference was detected between BM-MSC and ASC in the percentage inhibition (Figure 2).

\section{BM-MSC and ASC downregulate alloreactivity in vivo}

After confirmation of immunosuppressive capability in vitro, we investigated the effect of IFN- $\gamma$-stimulated BM-MSC and ASC on leukocyte recruitment into human skin in a huSCID mouse model (Figure 3A). Human skin was transplanted and engrafted well within 6 weeks (Figure 3B). After adoptive transfer of human PBMCs into

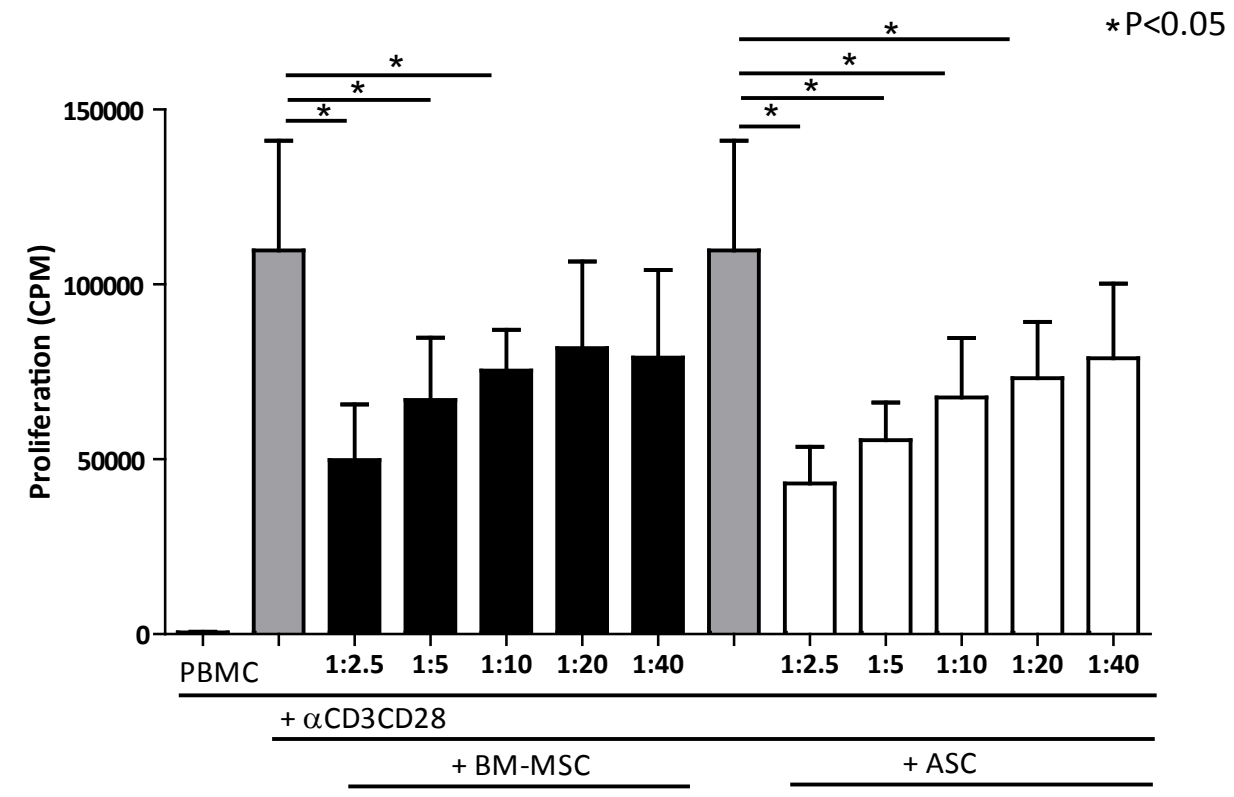

Figure 2: Inhibition of aCD3CD28 stimulated PBMC by INFy stimulated BM-MSC $(n=4)$ and ASC $(n=4)$. Means (SD) are depicted, ${ }^{*}$ represents $P<0.05$. 
Citation: Roemeling-van Rhijn, Khairoun M, Korevaar SS, Lievers E, Leuning DG, et al. (2013) Human Bone Marrow- and Adipose Tissue-derived Mesenchymal Stromal Cells are Immunosuppressive In vitro and in a Humanized Allograft Rejection Model. J Stem Cell Res Ther S6: 001. doi:10.4172/2157-7633.S6-001

Page 5 of 8

the mouse by intraperitoneal injection, there was a marked infiltration of CD45+ leukocytes in the skin graft at day 14 (Figures 3C and 3D). Despite this marked leukocyte infiltration in the graft, skin integrity of the huSCID mice remained intact and did not slough. This is probably due to the maintenance of blood flow by the murine vasculature as also described previously $[49,50]$. The infiltrating CD45+ cells consisted of
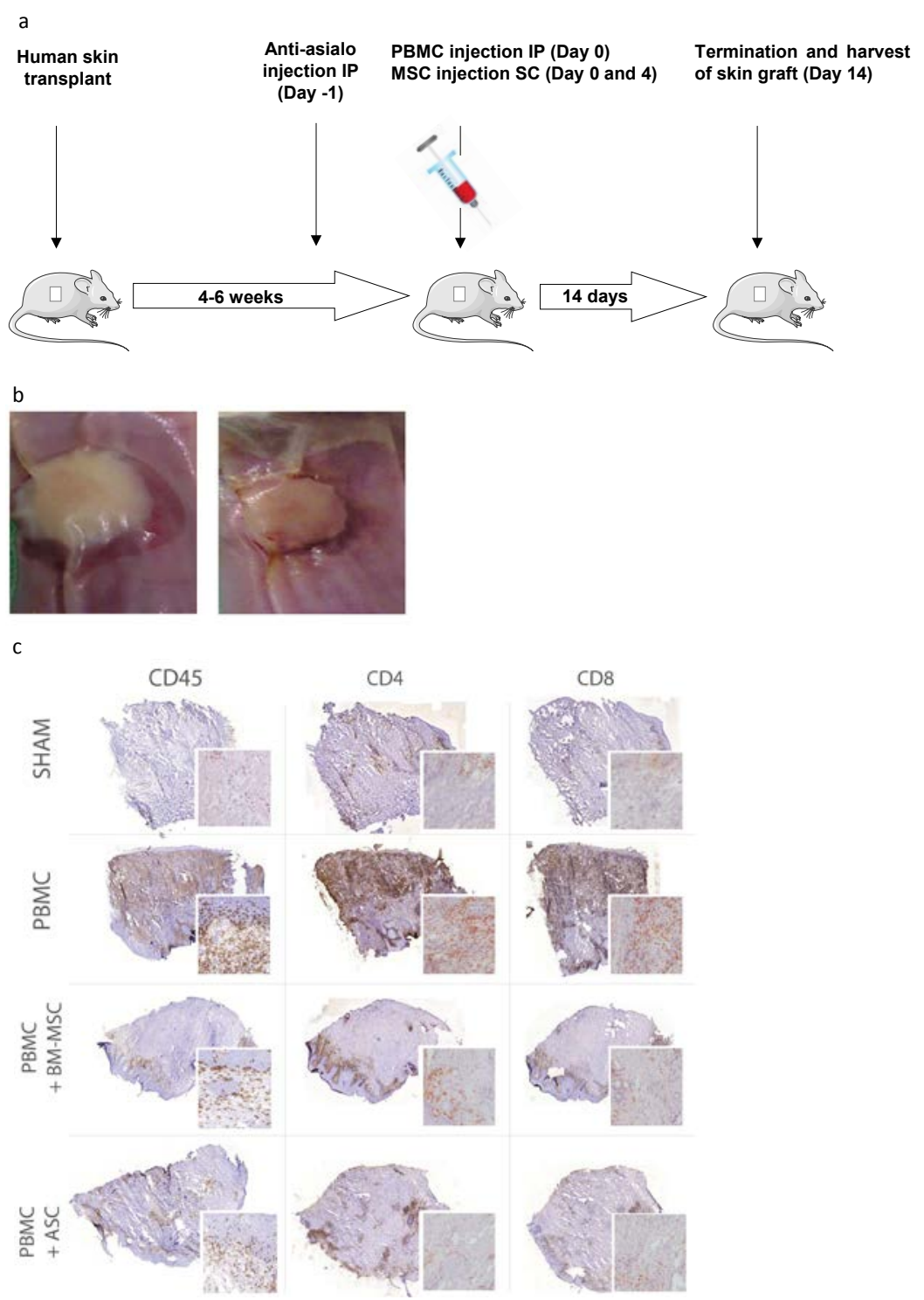

CD45

CD4
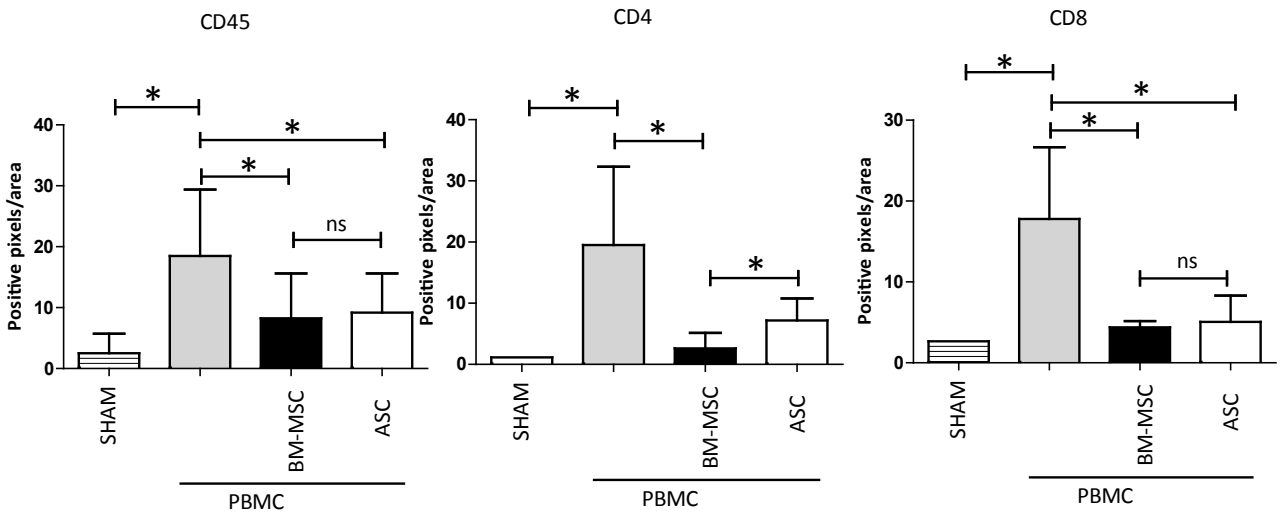
Citation: Roemeling-van Rhijn, Khairoun M, Korevaar SS, Lievers E, Leuning DG, et al. (2013) Human Bone Marrow- and Adipose Tissue-derived Mesenchymal Stromal Cells are Immunosuppressive In vitro and in a Humanized Allograft Rejection Model. J Stem Cell Res Ther S6: 001. doi:10.4172/2157-7633.S6-001

Page 6 of 8
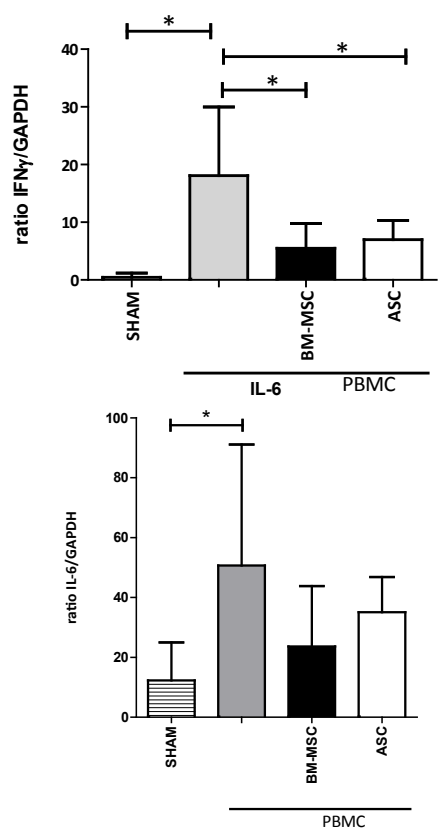

$* \mathrm{P}<0.05$

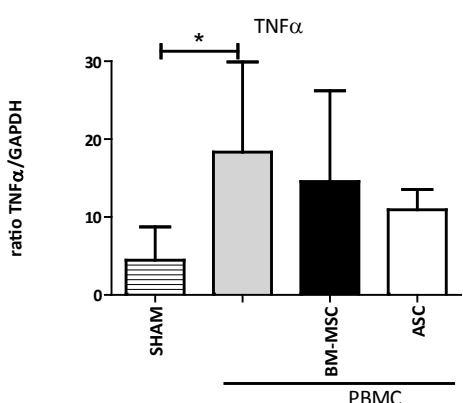

IL-1 $\beta$

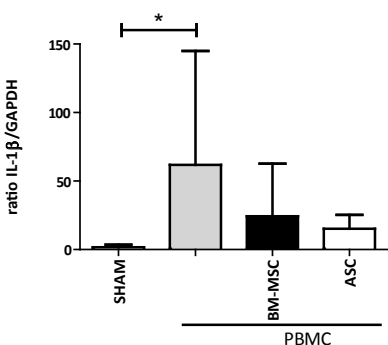

Figure 3: (A) HuSCID mouse model: human skin is transplanted; mouse NK cells are depleted using anti-asialo GM1 injection at day-1; allogeneic PBMC are injected intraperitoneal at day 0 ; MSC are injected on day 0 and day 4; and after 14 days, mice are sacrificed and skin grafts are harvested. (B) Representative example of engraftment process of skin graft, pictures taken at 12 and 16 days after skin graft transplantation. (C) Immunohistological evaluation of explanted skin grafts. Staining for CD45+, CD4+ and CD8+ T cells of skin grafts explanted from mice receiving only a skin transplant (SHAM group); mice receiving skin graft and PBMC; mice receiving skin graft, PBMC and BM-MSC; and mice receiving skin graft, PBMC and ASC. Representative biopsies are shown. (D) Quantitative evaluation of CD45+, CD4+ and CD8+ cells in biopsies of study groups. Data represent mean (SD), "indicates $P<0.05$. (E) mRNA gene expression in explanted skin grafts of IFNy, TNFa, IL-6 and IL-1 $\beta$ of study groups. Ratio gene/GAPDH x1000 is shown. Data represent mean (SD), "indicates $\mathrm{P}<0.05$.

both CD4+ and CD8+ T cells (Figures 3C and 3D). Mice not receiving an adoptive transfer of human PBMCs did not demonstrate leukocyte infiltration (SHAM group, Figures 3C and 3D). Administration of BM-MSC or ASC at day 0 and day 4 after allogeneic PBMC injection resulted in a significant reduction of $\mathrm{CD} 45+, \mathrm{CD} 4+$ and $\mathrm{CD} 8+\mathrm{T}$ cell infiltration (Figures 3C and 3D). RT-PCR analysis for expression of various pro-inflammatory human cytokines was performed on the explanted skin grafts of the mice. The mice that had received PBMC revealed a significant increase in mRNA expression of IFN $\gamma, \mathrm{TNF} \alpha$, IL-6 and IL1- $\beta$ indicating inflammation compared to mice with skin grafts only (Figure $3 \mathrm{E}$ ). When mice with engrafted skin grafts were treated with BM-MSC or ASC after PBMC injection, expression of IFN $\gamma$ significantly decreased (Figure $3 \mathrm{E}$ ). Expression of TNFa, IL-1 $\beta$ and IL- 6 was also reduced after BM-MSC or ASC treatment, although these differences did not reach statistical significance.

\section{Discussion}

We found that MSC derived from bone marrow and adipose tissue was capable of immune suppression in vitro and inhibition of $\mathrm{T}$ cell mediated alloreactivity in vivo. These results are important for future clinical application of MSC. MSC are emerging as a cell therapeutic agent in the field of transplantation with now four completed trails in kidney transplant recipients and multiple trails in preparation [29$31,33,51]$. However, currently, there is no consensus considering the optimal source for the isolation of MSC for clinical application.

Our finding that BM-MSC and ASC are both effective indicates that the choice between BM-MSC and ASC for clinical application can be made upon practical considerations. This is important as, despite the numerous studies published on MSC and immune modulation, only a few compared their immunosuppressive capacity. Moreover, in the field of transplantation, no humanized mouse models have been used to evaluate the effect of MSC. In the present study, we first evaluated the in vitro immunosuppressive capacities of the MSC. We found that BM-MSC and ASC both express CXCL-10, TGF $\beta$ and IDO. The chemoattractive CXCL-10, the immune regulatory TGF $\beta$ and antiproliferative IDO are known factors via which MSC excert their immune modulating properties $[13,52,53]$. Thus, our results confirm the immunosuppressive potential of both types of MSC. Further, as it is known that an inflammatory environment can stimulate the immunosuppressive MSC function [54], we evaluated their response to IFN $\gamma$ stimulation. Upon IFN $\gamma$ stimulation, we found that IDO expression and activity was increased in both BM-MSC and ASC. This is in line with the notion that an inflammatory environment, in this study simulated with IFN $\gamma$, can potentiate MSC efficacy in both BMMSC and ASC.

In aCD3aCD28-induced PBMC proliferation assays we found BM-MSC and ASC both capable of dose dependent inhibition. These results confirm previous data showing that BM-MSC and ASC have the capacity to inhibit proliferation of alloantigen and mitogen activated PBMC $[17,39,55]$ and justifies examination of these cell populations in a preclinical transplant model.

Multiple animal studies have shown the potential of BM-MSC [12,25-27,45,46] and ASC [28] to ameliorate ischemia reperfusion injury or alloreactivity. Yet, as mentioned before, human BM-MSC and human ASC have not been evaluated in a humanized transplant model. 
Citation: Roemeling-van Rhijn, Khairoun M, Korevaar SS, Lievers E, Leuning DG, et al. (2013) Human Bone Marrow- and Adipose Tissue-derived Mesenchymal Stromal Cells are Immunosuppressive In vitro and in a Humanized Allograft Rejection Model. J Stem Cell Res Ther S6: 001. doi:10.4172/2157-7633.S6-001

Page 7 of 8

Issa et al. used such a humanized model for evaluation of regulatory $\mathrm{T}$ cell (Tregs) therapy. This model enabled the authors to study the effect of ex vivo-expanded Tregs and found them capable of inhibition of skin graft rejection [56]. Here, for the first time, we used such a unique humanized mouse model for evaluation of MSC treatment in allograft rejection. We found that BM-MSC and ASC were effective in inhibiting alloreactivity. Alloreactivity was marked by recruitment of CD45+ cells which consisted of CD4+ and CD $8+$ T cells and IFN $\gamma$, TNF $\alpha$, IL- $1 \beta$ and Il-6 mRNA expression was increased in the explanted skin grafts. Local administration of BM-MSC as well as ASC reduced inflammation by inhibiting the recruitment of T cells and decreasing IFN $\gamma$, TNFa, IL-6 and IL-1 $\beta$ expression in the skin grafts. These results support the use of BM-MSC and ASC to treat transplant rejection.

In conclusion, the immunosuppressive potential of BM-MSC and ASC has been highlighted in the present study. Our experiments confirm the immunosuppressive capacities of BM-MSC and ASC in vitro. By extending our investigations to a humanised transplant model our data underscore the potential of BM-MSC and ASC therapy in clinical transplantation.

\section{Acknowledgments}

We would like to acknowledge Dr. Dor FJMF, Dr. Kimenai HJAN, Dr. Terkivatan $\mathrm{T}$ and Dr. Tran TCK of the Department of Surgery of the Erasmus MC for the collection of the adipose tissue. This work was supported by the Nefrosearch Grant to MEJ Reinders.

\section{References}

1. Friedenstein AJ, Petrakova KV, Kurolesova AI, Frolova GP (1968) Heterotopic of bone marrow. Analysis of precursor cells for osteogenic and hematopoietic tissues. Transplantation 6: 230-247.

2. Caplan Al (1991) Mesenchymal stem cells. J Orthop Res 9: 641-650.

3. Bianco P, Robey PG, Simmons PJ (2008) Mesenchymal stem cells: revisiting history, concepts, and assays. Cell Stem Cell 2: 313-319.

4. Horwitz EM, Le Blanc K, Dominici M, Mueller I, Slaper-Cortenbach I, et al. (2005) Clarification of the nomenclature for MSC: The International Society for Cellular Therapy position statement. Cytotherapy 7: 393-395.

5. Reinders ME, Leuning DG, de Fijter JW, Hoogduijn MJ, Rabelink TJ (2013) Mesenchymal Stromal Cell Therapy for Cardio Renal Disorders. Curr pharm Des.

6. Hoogduijn MJ, Crop MJ, Peeters AM, Van Osch GJ, Balk AH, et al. (2007) Human heart, spleen, and perirenal fat-derived mesenchymal stem cells have immunomodulatory capacities. Stem Cells Dev 16: 597-604.

7. da Silva Meirelles L, Chagastelles PC, Nardi NB (2006) Mesenchymal stem cells reside in virtually all post-natal organs and tissues. J Cell Sci 119: 2204 2213.

8. Mosna F, Sensebe L, Krampera M (2010) Human bone marrow and adipose tissue mesenchymal stem cells: a user's guide. Stem Cells Dev 19: 1449-1470.

9. in 't Anker PS, Noort WA, Scherjon SA, Kleijburg-van der Keur C, Kruisselbrink AB, et al. (2003) Mesenchymal stem cells in human second-trimester bone marrow, liver, lung, and spleen exhibit a similar immunophenotype but a heterogeneous multilineage differentiation potential. Haematologica 88: 845852

10. Zuk PA, Zhu M, Mizuno H, Huang J, Futrell JW, et al. (2001) Multilineage cells from human adipose tissue: implications for cell-based therapies. Tissue Eng 7: 211-228.

11. Dominici M, Le Blanc K, Mueller I, Slaper-Cortenbach I, Marini F, et al. (2006) Minimal criteria for defining multipotent mesenchymal stromal cells. The International Society for Cellular Therapy position statement. Cytotherapy 8: 315-317

12. Bartholomew A, Sturgeon C, Siatskas M, Ferrer K, Mclntosh K, et al. (2002) Mesenchymal stem cells suppress lymphocyte proliferation in vitro and prolong skin graft survival in vivo. Exp Hematol 30: 42-48.

13. Di Nicola M, Carlo-Stella C, Magni M, Milanesi M, Longoni PD, et al. (2002)
Human bone marrow stromal cells suppress T-lymphocyte proliferation induced by cellular or nonspecific mitogenic stimuli. Blood 99: 3838-3843.

14. Krampera M, Cosmi L, Angeli R, Pasini A, Liotta F, et al. (2006) Role for interferon-gamma in the immunomodulatory activity of human bone marrow mesenchymal stem cells. Stem Cells 24: 386-398.

15. Crop MJ, Baan CC, Korevaar SS, ljzermans JN, Pescatori M, et al. (2010) Inflammatory conditions affect gene expression and function of human adipose tissue-derived mesenchymal stem cells. Clin Exp Immunol 162: 474-486.

16. Polchert D, Sobinsky J, Douglas G, Kidd M, Moadsiri A, et al. (2008) IFNgamma activation of mesenchymal stem cells for treatment and prevention of graft versus host disease. Eur J Immunol 38: 1745-1755.

17. Yanez R, Lamana ML, Garcia-Castro J, Colmenero I, Ramirez M, et al. (2006) Adipose tissue-derived mesenchymal stem cells have in vivo immunosuppressive properties applicable for the control of the graft-versushost disease. Stem Cells 24: 2582-2591.

18. Morigi M, Imberti B, Zoja C, Corna D, Tomasoni S, et al. (2004) Mesenchyma stem cells are renotropic, helping to repair the kidney and improve function in acute renal failure. J Am Soc Nephrol 15: 1794-1804.

19. Chen YL, Tsai TH, Chua S, Yip HK (2011) Adipose-Derived Mesenchymal Stem Cell Protects Kidneys Against Ischemia-Reperfusion Injury Through Suppressing Oxidative Stress and Inflammatory Reaction. Circulation 124.

20. Parekkadan B, van Poll D, Suganuma K, Carter EA, Berthiaume F, et al. (2007) Mesenchymal stem cell-derived molecules reverse fulminant hepatic failure. PLoS One 2: e941.

21. Banas A, Teratani T, Yamamoto Y, Tokuhara M, Takeshita F, et al. (2009) Rapid hepatic fate specification of adipose-derived stem cells and their therapeutic potential for liver failure. J Gastroenterol Hepatol 24: 70-77.

22. Le Blanc K, Frassoni F, Ball L, Locatelli F, Roelofs H, et al. (2008) Mesenchyma stem cells for treatment of steroid-resistant, severe, acute graft-versus-host disease: a phase II study. Lancet 371: 1579-1586.

23. Kharaziha P, Hellstrom PM, Noorinayer B, Farzaneh F, Aghajani K, et al (2009) Improvement of liver function in liver cirrhosis patients after autologous mesenchymal stem cell injection: a phase I-II clinical trial. Eur J Gastroentero Hepatol 21: 1199-1205

24. Duijvestein M, Vos AC, Roelofs H, Wildenberg ME, Wendrich BB, et al. (2010) Autologous bone marrow-derived mesenchymal stromal cell treatment for refractory luminal Crohn's disease: results of a phase I study. Gut 59: 16621669.

25. Casiraghi F, Azzollini N, Cassis P, Imberti B, Morigi M, et al. (2008) Pretransplan infusion of mesenchymal stem cells prolongs the survival of a semiallogeneic heart transplant through the generation of regulatory T cells. J Immunol 181: 3933-3946.

26. Zhou HP, Yi DH, Yu SQ, Sun GC, Cui Q, et al. (2006) Administration of donor-derived mesenchymal stem cells can prolong the survival of rat cardiac allograft. Transplant Proc 38: 3046-3051.

27. Franquesa M, Herrero E, Torras J, Ripoll E, Flaquer M, et al. (2012) Mesenchymal stem cell therapy prevents interstitial fibrosis and tubular atrophy in a rat kidney allograft model. Stem Cells Dev 21: 3125-3135.

28. Wan CD, Cheng R, Wang HB, Liu T (2008) Immunomodulatory effects of mesenchymal stem cells derived from adipose tissues in a rat orthotopic liver transplantation model. Hepatobiliary Pancreat Dis Int 7: 29-33.

29. Tan J, Wu W, Xu X, Liao L, Zheng F, et al. (2012) Induction therapy with autologous mesenchymal stem cells in living-related kidney transplants: a randomized controlled trial. JAMA 307: 1169-1177.

30. Perico N, Casiraghi F, Introna M, Gotti E, Todeschini M, et al. (2011) Autologous mesenchymal stromal cells and kidney transplantation: a pilot study of safety and clinical feasibility. Clin J Am Soc Nephrol 6: 412-422.

31. Reinders ME, de Fijter JW, Roelofs H, Bajema IM, de Vries DK, et al. (2013) Autologous bone marrow-derived mesenchymal stromal cells for the treatment of allograft rejection after renal transplantation: results of a phase I study. Stem Cells Transl Med 2: 107-111.

32. Popp FC, Fillenberg B, Eggenhofer E, Renner P, Dillmann J, et al. (2011) Safety and feasibility of third-party multipotent adult progenitor cells for immunomodulation therapy after liver transplantation - a phase I study (MITRANSPLANTATION-I). J TransI Med 9: 124 
Citation: Roemeling-van Rhijn, Khairoun M, Korevaar SS, Lievers E, Leuning DG, et al. (2013) Human Bone Marrow- and Adipose Tissue-derived Mesenchymal Stromal Cells are Immunosuppressive In vitro and in a Humanized Allograft Rejection Model. J Stem Cell Res Ther S6: 001. doi:10.4172/2157-7633.S6-001

33. Peng Y, Ke M, Xu L, Liu L, Chen X, et al. (2013) Donor-derived mesenchymal stem cells combined with low-dose tacrolimus prevent acute rejection after renal transplantation: a clinical pilot study. Transplantation 95: 161-168.

34. Strioga M, Viswanathan S, Darinskas A, Slaby O, Michalek J (2012) Same or Not the Same? Comparison of Adipose Tissue-Derived Versus Bone MarrowDerived Mesenchymal Stem and Stromal Cells. Stem Cells Dev 21: 2724-2752.

35. Fraser JK, Wulur I, Alfonso Z, Hedrick MH (2006) Fat tissue: an underappreciated source of stem cells for biotechnology. Trends Biotechnol 24: 150-154

36. Kern S, Eichler H, Stoeve J, Kluter H, Bieback K (2006) Comparative analysis of mesenchymal stem cells from bone marrow, umbilical cord blood, or adipose tissue. Stem Cells 24: 1294-1301.

37. Izadpanah R, Trygg C, Patel B, Kriedt C, Dufour J, et al. (2006) Biologic properties of mesenchymal stem cells derived from bone marrow and adipose tissue. J Cell Biochem 99: 1285-1297.

38. Maumus M, Peyrafitte JA, D'Angelo R, Fournier-Wirth C, Bouloumie A, et al. (2011) Native human adipose stromal cells: localization, morphology and phenotype. Int J Obes (Lond) 35: 1141-1153.

39. Puissant B, Barreau C, Bourin P, Clavel C, Corre J, et al. (2005) Immunomodulatory effect of human adipose tissue-derived adult stem cells: comparison with bone marrow mesenchymal stem cells. Br J Haematol 129: 118-129.

40. Krampera M, Glennie S, Dyson J, Scott D, Laylor R, et al. (2003) Bone marrow mesenchymal stem cells inhibit the response of naive and memory antigenspecific T cells to their cognate peptide. Blood 101: 3722-3729.

41. Le Blanc K, Tammik L, Sundberg B, Haynesworth SE, Ringden O (2003) Mesenchymal stem cells inhibit and stimulate mixed lymphocyte cultures and mitogenic responses independently of the major histocompatibility complex. Scand J Immunol 57: 11-20.

42. Crop M, Baan CC, Korevaar SS, ljzermans JN, Weimar W, et al. (2010) Human adipose tissue-derived mesenchymal stem cells induce explosive T-cell proliferation. Stem Cells Dev 19: 1843-1853.

43. Gonzalez-Rey E, Anderson P, Gonzalez MA, Rico L, Buscher D, et al. (2009) Human adult stem cells derived from adipose tissue protect against experimental colitis and sepsis. Gut 58: 929-939.

44. Roemeling-van Rhijn M, Reinders ME, de Klein A, Douben H, Korevaar SS, et al. (2012) Mesenchymal stem cells derived from adipose tissue are not affected by renal disease. Kidney Int 82: 748-758.
45. Hong ZF, Huang XJ, Yin ZY, Zhao WX, Wang XM (2009) Immunosuppressive function of bone marrow mesenchymal stem cells on acute rejection of liver allografts in rats. Transplant Proc 41: 403-409.

46. Zhang W, Qin C, Zhou ZM (2007) Mesenchymal Stem Cells Modulate Immune Responses Combined With Cyclosporine in a Rat Renal Transplantation Model. Transplant Proc 39: 3404-3408.

47. Ball LM, Bernardo ME, Roelofs H, Lankester A, Cometa A, et al. (2007) Cotransplantation of ex vivo expanded mesenchymal stem cells accelerates lymphocyte recovery and may reduce the risk of graft failure in haploidentical hematopoietic stem-cell transplantation. Blood 110: 2764-2767.

48. Hoogduijn MJ, Roemeling-van Rhijn M, Engela AU, Korevaar SS, Mensah FK et al. (2013) Mesenchymal Stem Cells Induce an Inflammatory Response after Intravenous Infusion. Stem Cells Dev 22: 2825-2835.

49. Moulton KS, Melder RJ, Dharnidharka VR, Hardin-Young J, Jain RK, et al (1999) Angiogenesis in the huPBL-SCID model of human transplant rejection. Transplantation 67: 1626-1631.

50. Reinders ME, Sho M, Izawa A, Wang P, Mukhopadhyay D, et al. (2003) Proinflammatory functions of vascular endothelial growth factor in alloimmunity. $\mathrm{J}$ Clin Invest 112: 1655-1665

51. Lee H, Park JB, Lee S, Baek S, Kim H, et al. (2013) Intra-osseous injection of donor mesenchymal stem cell (MSC) into the bone marrow in living donor kidney transplantation; a pilot study. J Transl Med 11: 96.

52. Meisel R, Zibert A, Laryea M, Gobel U, Daubener W, et al. (2004) Human bone marrow stromal cells inhibit allogeneic $T$-cell responses by indoleamine 2,3-dioxygenase-mediated tryptophan degradation. Blood 103: 4619-4621.

53. Melief SM, Geutskens SB, Fibbe WE, Roelofs H (2013) Multipotent stromal cells skew monocytes towards an anti-inflammatory interleukin-10-producing phenotype by production of interleukin-6. Haematologica 98: 888-895

54. Krampera M, Pasini A, Pizzolo G, Cosmi L, Romagnani S, et al. (2006) Regenerative and immunomodulatory potential of mesenchymal stem cells. Curr Opin Pharmacol 6: 435-441.

55. Melief SM, Zwaginga JJ, Fibbe WE, Roelofs H (2013) Adipose tissue-derived multipotent stromal cells have a higher immunomodulatory capacity than their bone marrow-derived counterparts. Stem Cells Transl Med 2: 455-463.

56. Issa F, Hester J, Goto R, Nadig SN, Goodacre TE, Wood K (2010) Ex vivoexpanded human regulatory $T$ cells prevent the rejection of skin allografts in a humanized mouse model. Transplantation 90: 1321-1327. 